\title{
La recepción por el Tribunal Supremo de la Doctrina de la Vinculación Negativa de la Ordenanza Local al Principio de Legalidad Sancionadora
}

\author{
Francisco Toscano Gil \\ Becario FPDI \\ Universidad Pablo de Olavide
}

\begin{abstract}
SUMARIO: I. INTRODUCCIÓN. II. LOS ANTECEDENTES DE LA STS DE 29 DE SEPTIEMBRE DE 2003. III. LA DOCTRINA TRADICIONAL SOBRE EL PRINCIPIO DE LEGALIDAD SANCIONADORA EN EL ÁMBITO LOCAL. IV. LA REINTERPRETACIÓN DEL PRINCIPIO DE LEGALIDAD EN EL ÁMBITO SANCIONADOR LOCAL: LA RECEPCIÓN DE LA DOCTRINA DE LA VINCULACIÓN NEGATIVA POR LA STS DE 29 DE SEPTIEMBRE DE 2003. V. CONCLUSIONES. VI. ANEXO JURISPRUDENCIAL.
\end{abstract}

\section{INTRODUCCIÓN}

La Constitución Española de 1978 reconoce en su artículo 137 la autonomía local ${ }^{1}$. La potestad normativa local forma parte del núcleo fundamental del contenido de esta autonomía garantizado por la Constitución ${ }^{2}$. El producto de esta potestad es la norma local, cuya manifestación más usual, aunque no la única, es la llamada ordenanza local. Por tanto, podemos afirmar que a través de la norma local se manifiesta y materializa la autonomía local.

La ordenanza local es una norma de naturaleza reglamentaria, ya que los entes locales no tienen potestad legislativa. Esta naturaleza determina que la ley actúe

\footnotetext{
${ }^{1}$ El artículo 137 CE dice así:

"El Estado se organiza territorialmente en municipios, en provincias y en las Comunidades Autónomas que se constituyan.

Todas estas entidades gozan de autonomía para la gestión de sus respectivos intereses.”

${ }^{2}$ La potestad reglamentaria de los entes locales se reconoce en el artículo 4.1.a) de la Ley de Bases del Régimen Local, de 2 de abril de 1985.
} 
como el principal límite de la ordenanza local, conforme al principio de jerarquía normativa y al principio de legalidad, ambos recogidos en la Constitución ${ }^{3}$.

Ambos principios constitucionales, autonomía local y principio de legalidad, colisionan y entran en conflicto. Es necesario cohonestar estos principios, lograr su coexistencia en armonía. Lo que no es posible si uno de ellos crece a costa de restar espacio al otro. Para evitar una configuración del principio de legalidad excesivamente limitadora de la ordenanza local, y, por tanto, negadora de la autonomía local, se esgrimen por parte de algunos sectores de la doctrina española argumentos a favor de extender el campo de actuación de la ordenanza local. La solución pasa por reconocer las peculiaridades de la norma local, que, pese a ser norma de naturaleza reglamentaria, está dotada de características que la singularizan frente a los reglamentos estatales y autonómicos, haciéndola diferente. Esto supone una reinterpretación flexibilizadora del principio de legalidad, que facilite unas mayores posibilidades de actuación para la ordenanza local ${ }^{4}$.

La jurisprudencia, tanto del Tribunal Supremo como del Constitucional, se ha mostrado vacilante y contradictoria al definir las posibilidades de la ordenanza local en su relación con la ley ${ }^{5}$. Ha sido reacia a admitir las soluciones aportadas por la doctrina ante la problemática planteada por los límites que la ley implica para la ordenanza local. Si tenemos que resumir la postura jurisprudencial en esta materia, podemos definirla como contraria a admitir la reinterpretación de los principios de legalidad y de reserva de ley propugnados por nuestra doctrina ${ }^{6}$.

\footnotetext{
${ }^{3} \mathrm{El}$ artículo $9.3 \mathrm{CE}$ reconoce ambos principios, legalidad y jerarquía normativa, de la siguiente forma:

"La Constitución garantiza el principio de legalidad, la jerarquía normativa, la publicidad de las normas, la irretroactividad de las disposiciones sancionadoras no favorables o restrictivas de derechos individuales, la seguridad jurídica, la responsabilidad y la interdicción de la arbitrariedad de los poderes públicos".

${ }^{4}$ Por lo que hace a la extensa bibliografía que ha proporcionado nuestra doctrina sobre estas cuestiones, nos remitimos a las citas bibliográficas que iremos haciendo a nota a pie de página a lo largo de este trabajo.

${ }^{5}$ OrTega califica la posición del Tribunal Constitucional al respecto como "prudente y ambigua". Vid. Ortega Álvarez, Luis, "La potestad normativa local", en Font i Llovet, Tomás, Anuario del gobierno local 2001, Marcial Pons, Barcelona, 2001, pág. 40.

${ }^{6}$ Vid. Nieto García, Alejandro, Derecho Administrativo Sancionador, Tecnos, Madrid, 2002, pág. 126.

Sobre la jurisprudencia relativa al alcance de la ordenanza local respecto de los derechos de propiedad y de libertad de empresa, como materias reservadas a ley, vid. Blasco Díaz, José Luis, Ordenanza municipal y ley, Marcial Pons, Madrid, 2001, págs. 149-159.
} 
No obstante, también es cierto que, progresivamente, se ha ido abriendo una cierta línea favorable a admitir la posibilidad de matizar la reserva de ley en determinados ámbitos. De este modo, la reserva de ley deja de ser una institución de aplicación uniforme en todos los campos, y pasa a ser objeto de modulación en determinadas situaciones.

A pesar de todo esto, si nos fijamos en los últimos pronunciamientos del Tribunal Supremo en un ámbito concreto, el del Derecho sancionador local, y nos detenemos a analizar el grado de vinculación de la ordenanza local al principio de legalidad sancionadora, el criterio no ha sido siempre el mismo, y su jurisprudencia sigue siendo contradictoria. Unas veces, el Tribunal Supremo se ha mostrado más flexible, admitiendo una cierta modulación del principio de reserva de ley sancionadora en relación a la norma local. En otras ocasiones, la doctrina de este Tribunal ha sido bastante restrictiva para con las posibilidades de la ordenanza local ${ }^{7}$.

Ahora bien, es en los últimos años cuando nos encontramos con algunos pronunciamientos de ambos Tribunales bastante significativos, por lo que hace a la recepción de esta interpretación flexible de los principios de legalidad y de reserva de ley, y que deben ser tomados, sin duda, como un punto de inflexión al respecto en la jurisprudencia de los mismos.

Es fundamental la STC 233/1999, de 16 de diciembre (RTC 1999/233) ${ }^{8}$, por cuanto admite la posibilidad de modular la reserva de ley en lo local. Se trata de una reserva de ley tributaria ${ }^{9}$. De ahí a la modulación en el ámbito

\footnotetext{
7 Vid. Nieto García, Alejandro, Derecho Administrativo Sancionador, op. cit., págs. 495-532, donde NiETo recoge el contenido de alguna de estas sentencias. También es interesante el análisis jurisprudencial que realiza BALLESTEROS, en Ballesteros Fernández, Ángel y Gieure Le Caressant, Javier, Los reglamentos y ordenanzas locales. Estudio especial del Reglamento orgánico, Centro de Estudios Delta, Valencia, 2000, págs. 22-25, o en Ballesteros Fernández, Ángel, Manual de Administración local, Comares, Granada, 1998, págs. 201 y 202.

${ }^{8}$ De esta sentencia fue Ponente PABLO CACHÓN VILLAR.

${ }^{9}$ Sobre la modulación del principio de reserva de ley en el ámbito tributario local, vid. Bello Paredes, Santiago, Las ordenanzas locales en el vigente Derecho español. Alcance y articulación con la normativa estatal y autonómica, INAP, Madrid, 2002, págs. 170 y 225-246; Bello Paredes, Santiago, "La reserva de ley en el ámbito tributario local: una reflexión en torno a la Ley de Tasas Estatales y de Reordenación de las Prestaciones Patrimoniales de Carácter Público", Revista de Estudios de la Administración Local y Autonómica, núm. 280-281, 1999; Blasco Díaz, José Luis, Ordenanza municipal y ley, op. cit., págs. 211-235; Embid Irujo, Antonio, "Ordenanzas y reglamentos municipales”, en Muñoz Machado, Santiago, Tratado de Derecho municipal, Civitas, Madrid, 2003, pág. 541; Fernández
} 
sancionador local hay poca distancia. Y esa distancia la recorre la STC 132/2001, de 8 de junio (RTC 2001/132), primer pronunciamiento del Tribunal Constitucional admitiendo la posibilidad de relajar el límite que la reserva de ley implica para la ordenanza local en este ámbito ${ }^{10}$. Por último, debemos citar la reciente STS de 29 de septiembre de 2003 (RJ 2003/6487), de indudable relevancia por cuanto pretende sentar doctrina en la materia, con su innovadora y revolucionaria recepción de la doctrina de la vinculación negativa del principio de legalidad ${ }^{11}$.

Si la sentencia del Tribunal Constitucional que acabamos de mencionar da un paso importante al admitir la modulación de la reserva de ley en el ámbito sancionador local, la Sentencia del Tribunal Supremo, de 29 de septiembre de 2003 (RJ 2003/6487), da un paso más, mediante la recepción de la doctrina de la vinculación negativa de la ordenanza al principio de legalidad sancionadora.

La pretensión innovadora de la STS de 29 de septiembre de 2003 (RJ $2003 / 6487$ ), sus novedosas aportaciones en la construcción de una nueva doctrina sobre las relaciones entre la ley y la ordenanza local en la jurisprudencia española, y su carácter reciente, justifican por sí sólo el convertirla en el objeto de este trabajo.

Rodríguez, Tomás-Ramón, "La potestad reglamentaria de las Corporaciones locales", Cuadernos de Derecho Judicial Administración local,1995, págs. 211-213; LLiset Borrell, Francisco, Manual de Derecho local, El Consultor de los Ayuntamientos y de los Juzgados, Madrid, 2001, págs. 156-158, 559560, y 567; Ortega Álvarez, Luis, "La potestad normativa local", op. cit., págs. 50-53; Parejo Alfonso, Luciano, "La autonomía local en la Constitución”, en Muñoz Machado, Santiago, Tratado de Derecho municipal, Civitas, Madrid, 2003, pág. 86; Sánchez Goyanes, Enrique, La potestad normativa del municipio español: ordenanzas, reglamentos, planes urbanisticos, normas, El Consultor de los Ayuntamientos y de los Juzgados, Madrid, 2000, págs. 205-216.

${ }^{10}$ Sobre esta STC 132/2001, de 8 de junio (RTC 2001/132), cuyo Ponente fue también PABLO CACHÓN VILlAR, deben destacarse algunos estudios doctrinales. Así, vid. Bello Paredes, Santiago, "La reserva de la ley en el ámbito sancionador local, ¿Estamos ante el comienzo del fin de una larga disputa?”, Revista de Estudios de la Administración Local y Autonómica, núm. 286-287, 2001, págs. 297-299; Orduña Prada, Enrique, "Ordenanza municipal y potestad sancionadora: la sorprendente concisión de la STC 132/2001, de 8 de junio”, Revista de Estudios de la Administración Local y Autonómica, núm. 286-287, 2001, págs. 363-384.

Esta doctrina es confirmada con posterioridad por las STC 161/2003, de 15 de septiembre (RTC 2003/161), y STC 193/2003, de 27 de octubre (RTC 2003/193).

${ }^{11}$ Debemos reseñar que fue Mariano BaEna del Alcázar el Ponente de la citada STS, de 29 de septiembre de 2003 (RJ 2003/6487). 


\section{LOS ANTECEDENTES DE LA STS DE 29 DE SEPTIEMBRE DE 2003}

La sentencia que vamos a analizar trae causa de un recurso de casación interpuesto por el Ayuntamiento de Zaragoza ${ }^{12}$, el 8 de junio de 1998, contra Sentencia del Tribunal Superior de Justicia de Aragón, de 4 de febrero de 1998, que estimaba parcialmente el recurso contencioso administrativo interpuesto conjuntamente por Transportes Buera Sancho S.A. y otras empresas del ramo ${ }^{13}$, contra acuerdo del Pleno del Ayuntamiento de Zaragoza, de 24 de abril de 1995, por el que se aprobaba una ordenanza municipal reguladora de la ocupación de la vía pública con contenedores.

Esta ordenanza, en sus artículos 15 y 16, implementaba un régimen sancionador en el ámbito de su competencia, al regular las infracciones que pu-

12 El Ayuntamiento de Zaragoza interpone el recurso de casación invocando un solo motivo al amparo del artículo 95.1.4 ${ }^{\circ}$ de la hoy derogada Ley de la Jurisdicción Contencioso-Administrativa, de 27 de diciembre de 1996, consistente en "infracción de las normas del ordenamiento jurídico o de la jurisprudencia que fueren aplicables para resolver las cuestiones objeto de debate". $\mathrm{Si}$ bien es cierto que lo articula en cinco apartados, que son analizados uno por uno por el Tribunal Supremo, al entender que puede dárseles el tratamiento de distintos motivos de casación.

Los primeros cuatro apartados o motivos de casación se basan en la relajación del principio de reserva de ley en el ámbito sancionador local.

El motivo o apartado primero se fundamenta en la relajación de la exigencia de reserva de ley en materia de tipificación de infracciones y sanciones por la jurisprudencia del Tribunal Constitucional en los supuestos de existencia de relaciones de sujeción especial. Se sostiene por el Ayuntamiento que, en este caso, se da una relación de sujeción especial de los titulares de autorización para instalar contenedores en la vía pública.

El motivo o apartado segundo se refiere también a la relajación del principio de reserva de ley en este ámbito, por tratarse del relativo a la actuación de las entidades locales. La relajación que se produce, para ellas, del principio de reserva de ley tributaria, según doctrina del Tribunal Constitucional, es extrapolable al ámbito sancionador, cuando haya de ser conjugada con el principio constitucional de autonomía local.

El motivo o apartado tercero vuelve sobre esta tesis, basándose en la jurisprudencia constitucional sobre la legislación de régimen local, que entiende infringida en este caso.

El motivo o apartado cuarto alega infracción de los artículos 137 y 140 de la Constitución Española, así como de los preceptos aplicables de la LBRL, todos ellos articuladores del marco normativo del principio de autonomía local, y, como consecuencia de éste, de las potestades reglamentaria y sancionadora.

Por último, el motivo o apartado quinto, al margen de las consideraciones hechas por los apartados anteriores, entiende que sí que existe habilitación legal para la regulación de infracciones y sanciones que realiza la ordenanza, habilitación que sitúa en la Ley 42/1975, de 19 de noviembre, sobre Recogida y Tratamiento de los Desechos y Residuos Sólidos Urbanos, modificada por Real Decreto legislativo 1163/1986, de 13 de junio.

${ }^{13}$ Respecto de las empresas que interponen el recurso contencioso-administrativo, decir que se trata de empresas titulares de autorización para instalar contenedores en la vía pública. 
dieran cometerse contra las disposiciones de la propia ordenanza, así como las correspondientes infracciones a imponer por razón de las mismas. La ordenanza, por tanto, se ocupaba de tipificar infracciones y sanciones en el ámbito de la materia que regulaba.

Dicho atrevimiento habría de costarle caro al Ayuntamiento de Zaragoza, que fue el que dictó la ordenanza, ya que supuso la anulación de estos dos artículos por la Sentencia del Tribunal Superior de Justicia de Aragón, al estimar parcialmente el recurso interpuesto, precisamente en lo relativo a la anulación de estos preceptos. El problema estaba en la falta de cobertura legal de este régimen sancionador. Esta sentencia entiende, en su Fundamento Jurídico Séptimo, que la tipificación de infracciones y sanciones realizada por la citada ordenanza carece de cobertura legal, por lo que sus artículos 15 y 16 son contrarios a Derecho, ya que vulneran el principio de legalidad sancionadora del artículo 25.1 de la Constitución Española. La consecuencia es la anulación por el Tribunal de estos artículos.

Frente al argumento esgrimido por el Ayuntamiento de Zaragoza, que alegaba que en este caso existía una relación de sujeción especial, lo que evitaría la exigencia de ley previa habilitadora de cobertura legal, la sentencia del Tribunal a quo resuelve afirmando que, incluso en las relaciones de sujeción especial, es necesaria en todo caso la cobertura legal, al margen del alcance concreto de la misma, que sí sería discutible. Aunque no se considere siempre exigible una cobertura legal específica para cada una de las infracciones y sanciones, sí que se requiere, como mínimo, una ley que establezca unas normas genéricas.

El Tribunal concluye que, pese a la potestad reglamentaria reconocida a los Ayuntamientos por la Ley de Bases del Régimen Local, de 2 de abril de 1985 (en adelante LBRL), una ordenanza municipal no puede ser fuente primaria de un ordenamiento sancionador, ni siquiera en el ámbito de las relaciones de sujeción especial, lo que, a su vez, fundamenta en base a los artículos 127 y 129 de la Ley 30/92, de 26 de noviembre, de Régimen Jurídico de las Administraciones Públicas y del Procedimiento Administrativo Común (en adelante LRJPAC).

El Tribunal Superior de Justicia de Aragón se suma, así, a la corriente jurisprudencial del Tribunal Supremo en la que se apoya su pronunciamiento, consistente en una rigurosa concepción de las exigencias del principio de legalidad en el orden sancionador, incluso en el ámbito de las relaciones de sujeción especial. Otra cosa es que en este ámbito se abran mayores espacios para la colaboración reglamentaria. 


\section{LA DOCTRINA TRADICIONAL SOBRE EL PRINCIPIO DE LE- GALIDAD SANCIONADORA EN EL ÁMBITO LOCAL}

La Sentencia del Tribunal Supremo expone a lo largo de su Fundamento Jurídico Tercero el marco legal de la potestad sancionadora local, así como la doctrina jurisprudencial dominante en la materia, de la que resulta la interpretación tradicional de los principios de legalidad y de reserva de ley que suele sostenerse en este ámbito. Si bien, también es cierto que en este mismo Fundamento Jurídico asume la doctrina de la STC 132/2001, de 8 de junio (RTC 2001/132), moduladora de la reserva de ley en el ámbito sancionador local, que supone una reinterpretación de este principio. Otra cosa es que no sea esta doctrina la clave para resolver el caso al que está atendiendo. El Tribunal Supremo va a dar un paso aún más revolucionario, mediante la recepción de la doctrina de la vinculación negativa del principio de legalidad, en el ámbito sancionador local, que va a ser el argumento final que le lleve a fallar a favor de la adecuación al ordenamiento jurídico de la ordenanza cuestionada.

Luego veremos como llega el Tribunal Supremo a este resultado. Expongamos, por ahora, siguiendo la secuencia de esta sentencia, el marco legal descrito, comenzando por la legislación de aplicación general, que ha de tener como referente ineludible, y de partida, el artículo 25.1 de la Constitución Española, que dice así:

"Nadie puede ser condenado o sancionado por acciones $u$ omisiones que en el momento de producirse no constituyan delito, falta o infracción administrativa, según la legislación vigente en aquel momento".

Se consagra en este precepto, a nivel constitucional, el principio de legalidad en materia sancionadora. Este principio se presenta, según la doctrina y la jurisprudencia más autorizada, en dos vertientes, una vertiente material, o principio de tipicidad, y una vertiente formal, o principio de reserva de ley ${ }^{14}$.

\footnotetext{
${ }^{14}$ Respecto a esta distinción dentro del principio de legalidad, vid. Arias Martínez, María Antonia, "La potestad sancionadora de los entes locales y el principio de legalidad (a propósito de la STS de 29 de mayo de 1998)", Revista de Estudios de la Administración Local y Autonómica, núm. 280-281, 1999, págs. 591 y 592; Ballesteros Fernández, Ángel, Manual de Administración local, op. cit., pág. 199; Bello Paredes, Santiago, Las ordenanzas locales en el vigente Derecho español. Alcance y articulación con la normativa estatal y autonómica, op. cit., págs. 176 y 177; Bello Paredes, Santiago, "La reserva de la ley en el ámbito sancionador local, ¿Estamos ante el comienzo del fin de una larga disputa?”, op. cit., pág. 285, que cita en su apoyo las STC de 7 de abril de 1987, STC de 21 de enero de 1988 y STC de 8 de junio de 1988; Blasco Díaz, José Luis, Ordenanza municipal y ley, op. cit., pág. 179; Sánchez Goyanes, Enrique, La potestad normativa del municipio español: ordenanzas, reglamentos, planes urbanísticos, normas, op. cit., págs. 277-280, con especial atención a las citas jurisprudenciales al respecto.
} 
Conforme a la vertiente material del principio de legalidad o principio de tipicidad, se exige la previa determinación de toda infracción administrativa. Sólo pueden sancionarse aquellas infracciones que hayan sido previamente definidas. Si no hay previa determinación de la infracción, no cabe imponer sanciones por ella.

En función de la vertiente formal del principio de legalidad o principio de reserva de ley, la infracción administrativa sólo puede definirse por norma con rango legal. No pueden imponerse sanciones si no es en virtud de infracciones previamente determinadas por ley. El término "legislación" hay que entenderlo referido a ley. La norma que determine previamente la infracción ha de ser una ley.

El Tribunal Supremo afirma que el mandato del artículo 25.1 CE resulta reiterado y reforzado por los preceptos de la legislación ordinaria. Comienza por el análisis de los artículos 127 y 129 de la LRJPAC $^{15}$. Así, el artículo 127.1 LRJPAC, en su redacción anterior a la reforma llevada a cabo por la Ley 57/2003, de 16 de diciembre, de medidas para la modernización del gobierno local, que es la redacción a que se atiene la sentencia dado el momento en que se dicta, dispone lo siguiente:

"La potestad sancionadora de las Administraciones públicas, reconocida por la Constitución, se ejercerá cuando haya sido expresamente atribuida por una norma con rango de Ley, con aplicación del procedimiento previsto para su ejercicio y de acuerdo con lo establecido en este título".

Pues bien, este precepto supone la consagración a nivel de legislación ordinaria del principio de legalidad en materia sancionadora, por cuanto en él se exige habilitación legal expresa para el ejercicio de la potestad sancionadora. Si bien, la LRJPAC no se queda ahí, ya que establece, en el primer párrafo de su artículo 129.1, del cual citamos también la redacción anterior a la Ley $57 / 2003$, de 16 de diciembre, de medidas para la modernización del gobierno local, lo siguiente:

"Sólo constituyen infracciones administrativas las vulneraciones del Ordenamiento Jurídico previstas como tales infracciones por una Ley".

\footnotetext{
${ }^{15}$ Hay que tener en cuenta que esta interpretación pierde su sentido en el ámbito local con la nueva redacción que a estos preceptos da la Ley $57 / 2003$, de 16 de diciembre, de medidas para la modernización del gobierno local. La nueva dicción de los artículos 127.1 y 129.1 LRJPAC remite, cuando se trate de entes locales, al nuevo Título XI de la LBRL, rubricado "Tipificación de las infracciones y sanciones por las Entidades Locales en determinadas materias".
} 
Se recoge así el principio de legalidad en su doble vertiente, material y formal. Por lo que hace a la vertiente material del principio de legalidad, conocida como principio de tipicidad, aparece en la medida en que se dice que toda infracción administrativa ha de estar previamente definida como tal infracción. La vertiente formal del principio de legalidad, o principio de reserva de ley, implica que dicha predeterminación de la infracción administrativa habrá de hacerse por norma con rango de ley ${ }^{16}$.

Lo mismo, principios de tipicidad y de reserva de ley, pero con relación a las sanciones administrativas, se recoge en el artículo 129.2 LRJPAC, en el que se puede leer lo que sigue:

"Únicamente por la comisión de infracciones administrativas podrán imponerse sanciones que, en todo caso, estarán delimitadas por la Ley".

También se detiene el Tribunal Supremo en su exposición en citar el artículo 129.4 de la LRJPAC, el cual dispone que "las normas definidoras de infracciones y sanciones no serán susceptibles de aplicación analógica”.

La LRJPAC es de aplicación general a todas las Administraciones Públicas, también a la Administración local, advierte este Tribunal, por lo que, ya tan sólo con los artículos citados, parece imposible que puedan tipificarse infracciones y sanciones mediante norma sin rango legal, rango del que carecen las ordenanzas locales, cual es el caso de la ordenanza municipal del Ayuntamiento de Zaragoza.

La siguiente norma jurídica citada por el Tribunal Supremo, en su descripción del marco legal general aplicable a la potestad sancionadora local, es el Real Decreto 1398/1993, de 4 de agosto, por el que se aprueba el Reglamento del Procedimiento para el ejercicio de la Potestad Sancionadora (en adelante RPS $)^{17}$. Si bien, del articulado de este Reglamento resulta la posibili-

${ }^{16}$ Respecto a la reserva de ley en el ámbito sancionador local, vid. Ballesteros Fernández, Ángel y Gieure Le Caressant, Javier, Los reglamentos y ordenanzas locales. Estudio especial del Reglamento orgánico, op. cit., págs. 15-25; Embid Irujo, Antonio, "Ordenanzas y reglamentos municipales", op. cit., págs. 527-529, que se ocupa de describir el marco legal y constitucional de la potestad sancionadora local, así como las limitaciones y problemas que resultan del mismo; LLiset Borrell, Francisco, Manual de Derecho local, op. cit., págs. 601-605.

${ }^{17}$ Sobre el RPS se generó una interesante polémica doctrinal. A este respecto, es de interés citar, por un lado, la postura doctrinal contraria a la tipificación de infracciones y sanciones por ordenanza local, así, Arias Martínez, María Antonia, "La potestad sancionadora de los entes locales y el principio de legalidad (a propósito de la STS de 29 de mayo de 1998)", op. cit., págs. 604-608, en la que ARIAS considera que los artículos 1.2 y 2.2 contradicen los artículos 25 CE y 127 y 129 
dad de tipificar infracciones y sanciones mediante ordenanza local, para el Tribunal Supremo no es éste el dato fundamental. Lo importante es que, de su Exposición de Motivos, y también de su articulado, añadimos nosotros ${ }^{18}$, se deriva la necesidad de respetar el referente básico del principio de legalidad. Es cierto que esta norma admite la tipificación de infracciones y sanciones por ordenanza local, pero esta tipificación ha de producirse en términos de colaboración, sin obviar la existencia de una norma con rango legal que regule las infracciones y sanciones en términos generales.

En cualquier caso, lo cierto es que el Tribunal Supremo está admitiendo en esta sentencia, al no cuestionar este Reglamento, la modulación de la reserva de ley en el ámbito sancionador local que resulta del mismo ${ }^{19}$.

LRJPAC; Fernández Rodríguez, Tomás-Ramón, "La potestad reglamentaria de las Corporaciones locales”, op. cit., págs. 213-217, que critica que el RPS pretenda imponer el principio de autonomía local a costa de la reserva de ley, dando, para FERNÁNDEZ RoDRÍGUEz, el RPS "el más rotundo mentís al principio de legalidad en materia sancionadora” del artículo 25 CE; García de Enterría, Eduardo, "La problemática puesta en aplicación de la LRJ-PAC: el caso del Real Decreto 1398/1993, de 4 de agosto, que aprueba el Reglamento del procedimiento para el ejercicio de la potestad sancionadora. Nulidad radical del Reglamento y desintegración general del nuevo sistema legal", Revista Española de Derecho Administrativo, núm. 80, 1993, sostiene GARCíA DE ENTERRÍA que el RPS, al permitir, en sus artículos 1.2 y 2.2, que por ordenanza local puedan tipificarse infracciones y sanciones, contradice "de manera frontal, directa e inequívoca el artículo 25 de la Constitución y la Ley que pretende desarrollar”, lo que lo hace nulo de pleno derecho.

Por otro lado, deben citarse algunos de los pronunciamientos doctrinales favorables a la posibilidad de tipificar infracciones y sanciones por ordenanza, en el marco de la polémica generada por el RPS, así Bello Paredes, Santiago, "La reserva de la ley en el ámbito sancionador local, ¿Estamos ante el comienzo del fin de una larga disputa?”, op. cit., págs. 299-302, donde, frente a las afirmaciones vertidas por GARCía de ENTERría, señala BELlo, en el contexto de la doctrina de la STC 132/2001, de 8 de junio (RTC 2001/132), que es posible esta tipificación sin por ello generarse anarquía normativa alguna; Nieto García, Alejandro, Derecho Administrativo Sancionador, op. cit., págs. 119-127, en la que NIETo defiende que por ordenanza local se puedan tipificar infracciones y sanciones, con base a una matización de la reserva de ley, entiende que, pese a haber sido puesta en duda su legalidad, el RPS "se ha constituido en el máximo defensor de la eficacia sancionatoria de las Ordenanzas municipales”, y, por último, contesta a algunas de las afirmaciones sostenidas por GARCíA DE ENTERRÍA, cuya visión apocalíptica del panorama sancionatorio municipal estima algo excesiva; Pareja i Lozano, Carles, "Autonomía y potestad normativa de las Corporaciones Locales", Revista de Administración Pública, núm. 138, 1995, págs. 130-132, que formula algunas objeciones a lo sostenido por GARCÍA DE ENTERRÍA, al entender PAREJA que la tipificación de infracciones y sanciones por ordenanza local viene recogida expresamente en los artículos 57 al 59 del TRRL, además de resultar de una interpretación flexible de la reserva de ley en el ámbito sancionador avalada por la jurisprudencia.

18 Para ello, no hay más que ver el artículo 2.2 de este RPS, que dice así:

"Asimismo, las Entidades que integran la Administración Local, cuando tipifiquen como infracciones hechos y conductas mediante ordenanzas, y tipifiquen como infracción de ordenanzas el incumplimiento total o parcial de las obligaciones o prohibiciones establecidas en las mismas, al aplicarlas deberán respetar en todo caso las tipificaciones previstas en la Ley”.

${ }^{19} \mathrm{Si}$ acudimos al RPS, podemos ver como se recoge en varios de sus artículos, en concreto los artículos 1.2 y 2.2, la posibilidad de que por ordenanza local se tipifiquen infracciones y sancio- 
Una vez expuesto el marco legal de aplicación general, el Tribunal Supremo pasa a la exposición de las normas referidas a las entidades locales, aquellas que les otorgan potestades, comenzando por los fundamentales artículos 4.1.a) y f) de la LBRL, que son los que reconocen la atribución de potestad reglamentaria y sancionadora ${ }^{20}$ a los entes locales. Esta atribución de potestades forma parte del contenido propio de la autonomía local ${ }^{21}$.

El marco legal descrito se cierra con los artículos 55 y 59 del Real Decreto Legislativo 781/1986, de 18 de abril, por el que se aprueba el Texto Refundido de las Disposiciones Legales vigentes en materia de Régimen Local (en adelante TRRL). Por lo que hace al artículo 55 TRRL, en él se puede leer lo siguiente:

"En la esfera de su competencia, las Entidades locales podrán aprobar ordenanzas y reglamentos, y los Alcaldes dictar bandos. En ningún caso contendrán preceptos opuestos a las leyes".

Este precepto suscita diversas lecturas ${ }^{22}$, quedándose el Tribunal Supremo en este momento con que permite a las entidades locales aprobar válida-

nes, lo que se lee en sentido favorable a una modulación de la reserva de ley en el ámbito de la potestad sancionadora local.

${ }^{20}$ Para cumplir con el mandato de cobertura legal para el ejercicio de la potestad sancionadora, que resulta de los artículos 25.1 CE y 127.1 LRJPAC, no basta con la cobertura legal otorgada por el artículo 4.1.f) LBRL, también es necesaria cobertura legal expresa para el ejercicio de la potestad sancionadora en una materia concreta, para la concreta imposición de infracciones y sanciones.

Y es que, como advierte Blasco Díaz, en Blasco Díaz, José Luis, Ordenanza municipal y ley, op. cit., pág. 185, citando STS de 6 de febrero de 1996, hay que distinguir que:

"Una cosa es la potestad sancionadora, que reconoce el art. 41.f) LRBRL, y otra la potestad de definir infracciones administrativas y regular y calificar las sanciones que a ellas corresponden, por escasas en su cuantía que sean, pues para esto último, la definición de infracciones y determinación de las sanciones, el art. 25.1 de la Constitución exige la oportuna cobertura legal, sin que obviamente a ello obste el que la Corporación tenga las competencias y potestades precisas para regular una determinada materia"

En el mismo sentido, y sobre esta sentencia, vid. Ballesteros Fernández, Ángel y Gieure Le Caressant, Javier, Los reglamentos y ordenanzas locales. Estudio especial del Reglamento orgánico, op. cit., pág. 23; LLiset Borrell, Francisco, Manual de Derecho local, op. cit., págs. 602 y 603; Sánchez Goyanes, Enrique, La potestad normativa del municipio español: ordenanzas, reglamentos, planes urbanisticos, normas, op. cit., pág. 292.

${ }^{21}$ También se refiere el Tribunal Supremo al artículo 21.1.n) LBRL, donde se señala que una de las atribuciones del Alcalde es "sancionar las faltas de desobediencia a su autoridad o por infracción de las ordenanzas municipales, salvo en los casos en que tal facultad esté atribuida a otros órganos". Si bien, entiende el Supremo, en este precepto, más que una atribución de potestad al ente local, lo que hay es una especificación de la competencia del Alcalde.

${ }^{22}$ Para algunos, de este precepto resulta la más clara afirmación del principio de jerarquía normativa del artículo 9.3 CE, insistiéndose en la primacía de la ley sobre el reglamento, que aquí adopta la forma de ordenanza local. 
mente reglamentos, bajo la forma de ordenanzas locales, que nunca podrán contravenir a las leyes. No va a ser éste el único provecho que el Tribunal saque de este precepto, puesto que también va a utilizarlo para construir la argumentación que realiza en el Fundamento Jurídico Cuarto de esta sentencia.

\author{
Respecto del artículo 59 del TRRL ${ }^{23}$, en el mismo se puede leer la si- \\ guiente previsión:
}

"Las multas por infracción de Ordenanzas no podrán exceder, salvo previsión legal distinta, de 25.000 pesetas en Municipios de más de 500.000 habitantes; de

Para otros, más importante que esto es el matiz que supone el que en ningún caso se esté exigiendo por este precepto previa habilitación legal para dictar la ordenanza local, de lo que resulta la sustitución del tradicional principio de vinculación positiva del reglamento a la ley por el principio de la vinculación negativa en el ámbito de la norma local. Lo único que se dice por este precepto es que los entes locales pueden dictar ordenanzas en materias de su competencia, pero no que para ello requieran de previa habilitación legal. Al contrario, en función de su último inciso, se puede entender que basta con que la ordenanza local no contradiga lo regulado por ley. La ley se convierte así en un límite negativo para la ordenanza. No se abandona la idea de primacía de la ley, y, sin embargo, se introduce un matiz adicional que permite flexibilizar sus consecuencias.

Así lo entiende también el Consejo de Estado, que propugna la vinculación negativa de los entes locales a la Constitución y a las leyes, en su Dictamen núm. 1749/94, de 23 de febrero de 1995 (consideración $5^{\underline{a}}$ ).

A favor de esta interpretación del artículo 55 TRRL, vid. Blasco Díaz, José Luis, Ordenanza municipal y ley, op. cit., pág. 101; Jerez Calderón, José Joaquín, "La potestad reglamentaria local", en Arozamena Sierra, Jerónimo, El Derecho local en la doctrina del Consejo de Estado, BOE, Madrid, 2002, pág. 64; Nieto García, Alejandro, Derecho Administrativo Sancionador, op. cit., pág. 124, donde NIETO, en contestación a GARCÍA DE ENTERRÍA, insiste, al analizar el artículo 55 TRRL, en que la vinculación negativa del principio de legalidad supervive en algunos campos del Derecho español estatal. En contra se posiciona Bello PAREdes, que sostiene que este artículo "no supone una consagración del principio de legalidad en su vinculación negativa, sino que, al contrario, este precepto se refiere a la relación de dos normas jurídicas entre sî", en Bello Paredes, Santiago, "La reserva de la ley en el ámbito sancionador local, ¿Estamos ante el comienzo del fin de una larga disputa?", op. cit., pág. 291.

Luego nos detendremos en como el Tribunal Supremo, en el Fundamento Jurídico Cuarto de la sentencia que estamos comentando, recepciona esta doctrina a favor de la vinculación negativa del principio de legalidad en el ámbito sancionador local.

${ }^{23}$ No hay que olvidar que las cuantías de este artículo fueron actualizadas por la Disposición Adicional Única de la Ley 11/1999, de 21 de abril, de modificación de la LBRL y otras medidas legislativas adoptadas en el marco del Pacto local, disposición por la que hay que entenderla sustituido. En el mismo sentido, debe entenderse lo dispuesto por el nuevo artículo 141 de la LBRL, introducido por la Ley 57/2003, de 16 de diciembre, de medidas para la modernización del gobierno local, en la reforma que realiza de la LBRL. Si bien, con ella, cambia la técnica legislativa, por cuanto el tope máximo lo establece en función de la gravedad de la infracción. Nos limitamos aquí a dejar constancia de esto, ya que el Tribunal Supremo resuelve conforme al artículo 59 TRRL, que era la disposición vigente en el momento en que se dictó la ordenanza cuestionada. 
15.000 pesetas en los de 50.001 a 500.000; de 10.000 pesetas en los de 20.001 a 50.000; de 5.000 pesetas en los de 5.001 a 20.000; de 500 pesetas en los demás Municipios".

Según este precepto, en el supuesto de que la legislación sectorial que defina las sanciones a imponer por infracción de lo dispuesto en una ordenanza local no haya dispuesto otra cosa, habrá que estar a la predeterminación de la cuantía económica de las sanciones que se realiza en este artículo, que tiene carácter de norma básica ${ }^{24}$.

Para el Tribunal Supremo, conforme a este esquema, y a la doctrina general descrita, el fundamento de la sanción del incumplimiento de una ordenanza local estará siempre en una norma emanada del Estado o de una Comunidad Autónoma, ya que sólo estos entes pueden dictar normas con rango de ley en nuestro Derecho. Esta situación menoscaba claramente la potestad reglamentaria local ${ }^{25}$.

A la misma conclusión, la merma de la potestad reglamentaria local, provocada por la existencia de ordenanzas locales sin garantía de su cumplimiento, llega el Tribunal Supremo tras el examen de la doctrina jurisprudencial vigente y dominante, tanto del Tribunal Constitucional como del Supremo.

${ }^{24}$ El artículo 59 del TRRL es de los calificados como básico por la Disposición Final Séptima del TRRL.

${ }^{25}$ También es posible entender que en el artículo 59 TRRL hay una habilitación legal por parte del legislador estatal, para el caso de que el legislador sectorial no habilite al ente local para la imposición de sanciones. Si bien, la falta de previsión legal respecto de las infracciones sancionables, deja esta habilitación incompleta. Hay quien sostiene, como señalan BELlo PAREDES o BLASco DíAz, que basta con este artículo 59 TRRL, o con su actualización por la Disposición Adicional Única de la Ley 11/1999, para entender que hay cobertura legal de aquellas infracciones tipificadas por los entes locales a las que se impongan estas sanciones pecuniarias. Vid. Blasco Díaz, José Luis, Ordenanza municipal y ley, op. cit., págs. 176, 187 y 188; Bello Paredes, Santiago, "La reserva de la ley en el ámbito sancionador local, ¿Estamos ante el comienzo del fin de una larga disputa?", op. cit., pág. 293; ARIAS MARTíNEZ sostiene que "la cobertura legal que exige el principio de legalidad se cumple, en relación con la tipificación de las sanciones, en virtud del artículo 59 del TR", en Arias Martínez, María Antonia, "La potestad sancionadora de los entes locales y el principio de legalidad (a propósito de la STS de 29 de mayo de 1998)", op. cit., pág. 600; en la misma línea se pronuncia NIETO, para quien "la exigencia de tipificación legal de sanciones está sobradamente cumplida" con este precepto, en Nieto García, Alejandro, Derecho Administrativo Sancionador, op. cit., pág. 128.

En cualquier caso, el Tribunal Supremo va a tener en cuenta este artículo 59 del TRRL en la argumentación construida en el Fundamento Jurídico Cuarto de la sentencia que estamos comentando, de cara a flexibilizar la aplicación del principio de legalidad en esta materia. 
Por lo que hace a la doctrina del Tribunal Constitucional, tras destacar que su evolución ha tendido a atenuar la exigencia de reserva de ley para la tipificación de infracciones y sanciones, el Tribunal Supremo se detiene en el análisis concreto de la STC 132/2001, de 8 de junio (RTC 2001/132). Esta sentencia es importante, y le merece la pena al Tribunal Supremo detenerse en ella, por ser la primera que admite esta modulación en el ámbito sancionador local. Pese a ello, aunque el Tribunal Constitucional haya admitido esta modulación, cabiendo la posibilidad de tipificar infracciones y sanciones por ordenanza, esto no soluciona todos los problemas existentes en esta materia. La vigencia de la doctrina de la vinculación positiva del principio de legalidad sigue siendo un obstáculo insalvable para la potestad normativa local, que resulta por ello disminuida, con la consiguiente merma de la autonomía local.

La vinculación positiva del principio de legalidad supone que por ordenanza local no pueden tipificarse infracciones y sanciones si no existe ley previa que la habilite para ello. De nada sirve que el Tribunal Constitucional haya admitido que por ordenanza local puedan tipificarse infracciones y sanciones, si no existe previa ley habilitadora de esa tipificación. De este modo, si el legislador sectorial no habilita previamente a la ordenanza, ésta estará privada de la garantía de su cumplimiento mediante la aplicación de un régimen sancionador $^{26}$, dado que las posibles infracciones tipificadas en previsión de su incumplimiento, y las sanciones correspondientes, carecerían de cobertura legal. El olvido del legislador sectorial vetaría el cumplimiento de la ordenanza local, que resultaría por ello inaplicable.

En la misma línea se sitúa la doctrina jurisprudencial del Tribunal Supremo, que también exige previa habilitación legal para la tipificación de infracciones y sanciones por ordenanza local. El Tribunal se limita a citar algunas de sus más recientes sentencias al respecto, tales como la STS de 22 de septiembre de 1999 (RJ 1999/6728), y las STS de 4 de febrero (RJ 2002/2911), 12 de junio (RJ 2002/8201) y 15 de julio de 2002 (RJ 2002/10136).

Si bien, también es cierto, y de ello advierte, que algunas de sus sentencias han aplicado la jurisprudencia constitucional flexibilizadora de la reser-

${ }^{26}$ El Tribunal Supremo, en el Fundamento Jurídico Cuarto de la sentencia que estamos comentando, señala que, para que estemos ante una norma jurídica es indispensable que exista una garantía de la misma. No obstante, esta garantía no tiene porque consistir en un régimen sancionador que se active ante el incumplimiento de la norma. La garantía puede ser de otro tipo. Pese a todo, la existencia de un régimen sancionador sigue siendo la principal garantía de cualquier norma jurídica, además de ser, en el campo del Derecho público, un elemento fundamental para dotar de contenido a una potestad tan importante como es la potestad reglamentaria. 
va de ley, especialmente en los casos en que se dan relaciones de sujeción es$\operatorname{pecial}^{27}$.

\section{LA REINTERPRETACIÓN DEL PRINCIPIO DE LEGALIDAD EN EL ÁMBITO SANCIONADOR LOCAL: LA RECEPCIÓN DE LA DOCTRINA DE LA VINCULACIÓN NEGATIVA POR LA STS DE 29 DE SEPTIEMBRE DE 2003}

Esta deficiencia del sistema de fuentes requiere una interpretación integradora de la normativa vigente que salve los obstáculos generados, y permita recuperar la sustantividad de la mermada potestad normativa local, así como revigorizar la autonomía local de cuyo núcleo fundamental forma parte, así lo dice este Tribunal en el Fundamento Jurídico Cuarto. Esta nueva interpretación tendría una doble base o fundamento.

En primer lugar, la base relativa al principio de autonomía local, que hay que entender contravenido si persiste la aplicación de la doctrina tradicional, cuya problemática conduce a la merma de la potestad normativa local, ante la imposibilidad de garantizar el cumplimiento de las ordenanzas locales carentes de habilitación legal. La disminución de la potestad normativa local supone, a su vez, una disminución de la autonomía local, por cuanto la primera forma parte de su contenido. La autonomía local se convierte así en un importante argumento que proyectar sobre la potestad normativa local ${ }^{28}$.

\footnotetext{
${ }^{27}$ Para un análisis más completo de la modulación de la reserva de ley por la jurisprudencia cuando se trate de relaciones de sujeción especial, vid. Lasagabaster Herrarte, Iñaki, Las relaciones de sujeción especial, Civitas, Madrid, 1994.

${ }^{28}$ El Consejo de Estado, en su Dictamen núm. 1749/94, de 23 de febrero de 1995 (consideración $5^{\text {a }}$ ), esgrime el principio de autonomía local para justificar la necesidad de aplicar la doctrina de la vinculación negativa del principio de legalidad en el ámbito sancionador local.

Sobre el principio de autonomía local como catalizador de la necesidad de relajar el principio de legalidad y el de reserva de ley en el ámbito local, vid. Galán Galán, Alfredo, La potestad normativa autónoma local, Atelier, Barcelona, 2001, págs. 189-197 y 233-234; Jerez Calderón, José Joaquín, "La potestad reglamentaria local", op. cit., págs. 61-63; Ortega Álvarez, Luis, "La potestad normativa local”, op. cit., págs. 43 y 44. Por el contrario, para GarCía DE EnTERRía, el principio de autonomía local no es argumento suficiente para excusar una reserva constitucional de ley, vid. García de Enterría, Eduardo, "La problemática puesta en aplicación de la LRJ-PAC: el caso del Real Decreto 1398/1993, de 4 de agosto, que aprueba el Reglamento del procedimiento para el ejercicio de la potestad sancionadora. Nulidad radical del Reglamento y desintegración general del nuevo sistema legal", op. cit.
} 
En segundo lugar habría que estar a una base normativa en la que apoyar el nuevo enfoque interpretativo. Esta base normativa viene dada por el artículo 3.1 de la Carta Europea de la Autonomía Local (en adelante CEAL). La Carta es de 15 de octubre de 1985, y fue ratificada por España el 20 de enero de $1988^{29}$.

Debemos destacar, y valorar positivamente, el hecho de que el Tribunal Supremo en su sentencia aplique la CEAL. Este Tratado internacional es el texto normativo sobre la autonomía local más importante en el contexto europeo, factor de homogeneización del concepto de autonomía local a este nivel. El Tribunal Supremo señala que la Carta "constituye un importante instrumento de interpretación del principio de autonomía local que consagra la Constitución”. La CEAL forma parte del ordenamiento jurídico español desde su publicación en el BOE. Lo que la convierte en norma con valor y fuerza de ley, plenamente aplicable ante los Tribunales. La aplicación de la CEAL por el Supremo es bastante representativa de su importancia y trascendencia. No sólo despeja toda duda sobre su valor, sino que además debe acallar definitivamente cualquier voz discordante, que se alce en contra del valor normativo de la misma ${ }^{30}$.

El artículo 3.1 de la CEAL se ocupa de definir la autonomía local de la siguiente manera:

"Por autonomía local se entiende el derecho y la capacidad efectiva de las Entidades locales de ordenar y gestionar una parte importante de los asuntos públicos, en el marco de la Ley, bajo su propia responsabilidad y en beneficio de sus habitantes".

No es la referencia de este artículo a que la potestad normativa local se ejerza "en el marco de la ley", lo que interesa al Tribunal Supremo. Pues, la misma remisión, entiende el Tribunal, se hace en el artículo 55 TRRL, donde se dispone que las ordenanzas locales no pueden contener preceptos contrarios a las leyes. De tal modo que la CEAL, ratificada en 1988, no vendría a añadir nada nuevo al respecto a lo dispuesto por el TRRL, aprobado en 1986.

${ }^{29}$ Su publicación se produjo en BOE núm. 47, de 24 de febrero de 1989.

${ }^{30}$ El propio Tribunal Supremo, en el Fundamento Jurídico Cuarto de esta sentencia, insiste en la necesidad de aplicar la CEAL, dado que "nos obliga como elemento que es de nuestro ordenamiento jurídico". Sobre el valor de la CEAL dentro del ordenamiento jurídico español, vid. Parejo Alfonso, Luciano, "La autonomía local en la Constitución”, op. cit., págs. 107-109; Rodríguez Álvarez, José Manuel, La Carta Europea de la autonomía local. Su significación en el ordenamiento jurídico español, Hnos. Bayer, Barcelona, 1996, págs. 104-107, 111 y 161. 
Es otra cosa lo que interesa al Tribunal, lo verdaderamente relevante está en la referencia que se hace en la CEAL a la capacidad efectiva de ordenar una parte importante de los asuntos públicos. La definición de la autonomía local que realiza la CEAL incluye la capacidad efectiva de ordenar una parte importante de los asuntos públicos. Cuando la Carta dice "ordenar" se está refiriendo a ejercer la potestad normativa local.

Por todo ello, no es admisible que una ordenanza local, carezca de la más potente garantía de su cumplimiento, cual es la existencia de un régimen sancionador. Si esto fuera así, resultaría mermada la capacidad efectiva del ente local para el ejercicio de la potestad normativa local, a la que se refiere la CEAL como elemento fundamental de la definición de la autonomía local ${ }^{31}$. Ello iría en contra del principio de autonomía local recogido en nuestra Constitución, en la forma en que es definido e interpretado por el artículo 3.1 de la Carta, por lo que también contravendría este precepto. Y, como ya hemos visto, lo dispuesto por la CEAL tiene valor y fuerza de ley, y a ello hay que atenerse.

Para el Tribunal Supremo, una interpretación sensible a las necesidades sociales de los tiempos, acorde a la función de completar el ordenamiento jurídico que el artículo 1.6 del Código Civil atribuye a su jurisprudencia ${ }^{32}$, habrá de realizarse de forma integradora. Esta interpretación ha de ponderar el conflicto entre el principio de autonomía local y el de legalidad ${ }^{33}$, de manera favorable al de autonomía local, entendido en el sentido dispuesto por la CEAL. Esto es, entendido como principio que requiere de la efectividad del cumplimiento de la norma local para verse dotado de contenido sustantivo.

\footnotetext{
31 Respecto de la conexión entre autonomía local y potestad normativa local en el artículo 3.1 de la CEAL, vid. García Roca, Javier, "El concepto actual de autonomía local según el bloque de la constitucionalidad", Revista de Estudios de la Administración Local y Autonómica, núm. 282, 2000, págs. 45-47; Parejo Alfonso, Luciano, "La autonomía local en la Constitución”, op. cit., págs. 110111; Rodríguez Álvarez, José Manuel, La Carta Europea de la autonomía local. Su significación en el ordenamiento jurídico español, op. cit., págs. 87-91 y 120-123.

${ }^{32} \mathrm{El}$ artículo 1.6 del Código Civil de 1889 dispone que:

"La jurisprudencia complementará el ordenamiento jurídico con la doctrina que, de modo reiterado, establezca el Tribunal Supremo al interpretar y aplicar la ley, la costumbre y los principios generales del derecho”.

${ }^{33}$ Por lo que hace a la necesidad de cohonestar el principio de legalidad con el principio de autonomía local, vid. Bello Paredes, Santiago, "La reserva de la ley en el ámbito sancionador local, ¿Estamos ante el comienzo del fin de una larga disputa?”, op. cit., pág. 293, que sostiene que la armonización de ambos principios es la clave para resolver el problema; Blasco Díaz, José Luis, Ordenanza municipal y ley, op. cit., págs. 66 y 67, que entiende que hay que contextualizar el principio de legalidad con el principio de autonomía, desconocido en el momento de la formulación clásica del principio de legalidad.
} 
Una lectura de este tipo conducirá a admitir, con fundamento en los artículos 55 y 59 del TRRL, que mediante ordenanza local se tipifiquen infracciones y sanciones, extendiéndose a los supuestos analizados en la sentencia la tendencia de la jurisprudencia constitucional a flexibilizar el principio de reserva de ley. Incluso, también habría que admitir, con base en esta misma argumentación, que dicha tipificación se realice a pesar de la falta de habilitación legal previa, siempre y cuando esta tipificación sea garantía indispensable para el cumplimiento de la ordenanza local, necesaria para su efectividad, conforme al artículo 3.1 de la CEAL.

Con esta interpretación, el Tribunal Supremo está, por un lado, confirmando la doctrina del Tribunal Constitucional que admite la modulación de la reserva de ley en el ámbito sancionador local ${ }^{34}$. Por otro, está sustituyendo la doctrina de la vinculación positiva de la ordenanza local al principio de legalidad por la doctrina contraria, la de la vinculación negativa, según la cual la ley sería un mero límite negativo, pero no un instrumento habilitador ${ }^{35}$. Si

${ }^{34}$ Que, como ya nos hemos ocupado de señalar, se recoge en la STC 132/2001, de 8 de junio (RTC 2001/132).

35 Finalmente, y conforme a estas consideraciones, el Tribunal Supremo, en el Fundamento Jurídico Séptimo, lo que hace es estimar el recurso, acogiendo los motivos, o apartados, de casación segundo, tercero y cuarto, en los que se alegaba que la evolución y tendencias del Tribunal Supremo, y del Constitucional, en lo relativo a la relajación de la reserva constitucional de ley, han de conducir necesariamente a una interpretación favorable al principio de autonomía local.

Respecto del motivo o apartado primero de casación, en el Fundamento Jurídico Sexto, se analiza si entre el Ayuntamiento de Zaragoza y los titulares de autorizaciones para instalar contenedores en la vía pública existe o no una relación especial de sujeción que justifique relajar la reserva de ley en esta materia. El Tribunal Supremo concluye que puede sostenerse que exista relación especial de sujeción cuando se trate de titulares de concesiones o autorizaciones genéricas. Pero, no por ello, puede llevarse la tendencia a la relajación de la reserva de ley hasta un punto tal que quepa la tipificación sin la existencia de, al menos, una ley que fije criterios genéricos. Por ello, el Tribunal no acoge este motivo de casación. Se muestra de este modo coherente con su jurisprudencia más reciente, que exige habilitación legal aunque se esté ante una relación especial de sujeción, como pudimos ver en las STS de 10 de febrero de 1997 (RJ 1997/1407), STS de 8 de octubre de 2001 (RJ 2002/5862) y STS de 6 de junio de 2003 (RJ 2003/6857), que ya han sido referidas en este trabajo. Para un estudio completo de las relaciones especiales de sujeción, vid. Lasagabaster Herrarte, Iñaki, Las relaciones de sujeción especial, op. cit..

Por lo que hace al motivo de casación, o apartado, quinto, el Tribunal Supremo, en el Fundamento Jurídico Quinto, niega toda posibilidad de fundamentar en la Ley 42/1975, de 19 de noviembre, sobre Recogida y Tratamiento de los Desechos y Residuos Sólidos Urbanos, el régimen sancionador establecido por la ordenanza cuestionada. Además, destaca la contradicción que resulta de alegar este motivo de casación, y, al mismo tiempo, en los restantes motivos o apartados sostener la tesis de la necesidad de relajar la reserva de ley en esta materia, cosa que no sería necesaria si la ley estatal citada fuera realmente habilitante. 
bien, es cierto que la sentencia en ningún momento se refiere expresamente a ello, ya que no utiliza los términos "doctrina de la vinculación negativa". Pese a ello, es la recepción de esta doctrina la que se está produciendo con esta forma de proceder del Tribunal Supremo. Veamos, ahora, la forma en que se articula en la sentencia la puesta en marcha de la doctrina de la vinculación negativa de la ordenanza local al principio de legalidad, en el ámbito sancionador.

Para empezar, la tipificación referida sólo podrá hacerse en el caso de que tenga lugar sobre materias relativas a competencias nucleares de los entes locales que impliquen potestades implícitas de ordenación de las mismas ${ }^{36}$. Y en ningún caso podrán estas ordenanzas contener preceptos opuestos a las leyes, según resulta del 55 TRRL, ni mucho menos realizar esta tipificación si previamente ha sido ya hecha por ley sectorial.

Tratándose de otro tipo de competencias, competencias compartidas, cabrá igualmente llevar a cabo esta tipificación si el Estado o la Comunidad $\mathrm{Au}$ tónoma, a quien corresponda según el orden constitucional de competencias, ha olvidado ejercer su potestad legislativa con esta finalidad.

En cualquier caso, entiende el Alto Tribunal, las sanciones a imponer habrán de ser siempre de carácter pecuniario, pues a ello obliga lo dispuesto en el artículo 59 del TRRL ${ }^{37}$, a falta de previsión legal distinta. Y si algo falta en los supuestos que este Tribunal está analizando, es precisamente previsión legal.

También insta, en el mismo Fundamento Jurídico Cuarto, a que se respeten por estas normas, y en el ejercicio de la potestad sancionadora, los principios imperantes en el ámbito del Derecho administrativo sancionador, tales como el de proporcionalidad y audiencia al interesado, así como que se pondere la sanción a imponer en función de la gravedad de la infracción, valorando las características demográficas, económicas y sociales del ente local.

Por otra parte, en su Fundamento Jurídico Octavo, desestima el recurso contencioso administrativo interpuesto ante el Tribunal a quo, por entender que los artículos 15 y 16 de la ordenanza cuestionada son conforme a Derecho.

${ }^{36}$ La sentencia se refiere a materias tales como el uso del dominio o la organización de servicios exclusivamente locales.

${ }^{37}$ Este artículo 59 del TRRL debía leerse en la clave dada por la actualización de cuantías llevada a cabo por la Disposición Adicional Única de la Ley 11/1999, de 21 de abril, de modificación de la LBRL y otras medidas legislativas adoptadas en el marco del Pacto local. Hoy habría que atender a lo dispuesto por el nuevo artículo 141 de la LBRL, introducido por la reforma de la misma llevada a cabo por la Ley 57/2003, de 16 de diciembre, de medidas para la modernización del gobierno local. 
A su vez, advierte, ya en el Fundamento Jurídico Séptimo de la sentencia, de que la solución que se ha adoptado es plenamente democrática, dada la legitimación democrática del órgano que elabora la ordenanza local ${ }^{38}$. Lo que casa perfectamente con el principio de autodisposición de los destinatarios, pues son los propios destinatarios de la ordenanza local sancionadora los que la legitiman, en la medida en que se ven democráticamente representados por el órgano que la aprueba ${ }^{39}$.

Esta nueva interpretación, dice el Tribunal, implica que los artículos 127 y 129 de la LRJPAC no son, por tanto, plenamente aplicables a los entes locales. Su sentido sólo se alcanza en su aplicación a los entes titulares con potestad legislativa, esto es, el Estado y las Comunidades Autónomas. En cambio, para los entes locales, en los supuestos que se acaban de analizar, habría que estar a una aplicación flexible de estos preceptos. De este modo, el Tribunal Supremo admite que no se puede trasladar el modelo tradicional de relaciones entre ley y reglamento, diseñado por los artículos 127 y 129 LRJPAC, a las relaciones que se den entre ley y ordenanza local ${ }^{40}$.

\footnotetext{
${ }^{38}$ La legitimación democrática de las Corporaciones locales se utiliza como argumento por el Consejo de Estado, en su Dictamen núm. 1749/94, de 23 de febrero de 1995 (consideración $5^{\text {a }}$ ), para sostener la vigencia de la vinculación negativa del principio de legalidad en el ámbito sancionador local.

Por lo que hace al carácter democrático de las Corporaciones locales como argumento utilizado a favor de la relajación del principio de legalidad en el ámbito local, vid. Blasco Díaz, José Luis, Ordenanza municipal y ley, op. cit., pág. 71, que advierte que hay que tener en cuenta que "las Corporaciones locales se constituyen en uno de los canales para el ejercicio de la voluntad popular”, y que ésta se produce sin la mediación de la ley; Galán Galán, Alfredo, La potestad normativa autónoma local, op. cit., págs. 198-212 y 233-234; Jerez Calderón, José Joaquín, "La potestad reglamentaria local", op. cit., págs. 61-63; Orduña Prada, Enrique, "Ordenanza municipal y potestad sancionadora: la sorprendente concisión de la STC 132/2001, de 8 de junio", op. cit., págs. 374378; Ortega Álvarez, Luis, "La potestad normativa local", op. cit., págs. 44-48.
}

39 También se utiliza el principio de autodisposición como argumento a favor de la relajación del principio de legalidad en el ámbito local, entendiendo que las colectividades destinatarias de la ordenanza local se ven reflejadas directamente en el proceso de elaboración de la misma, pudiendo afirmarse que se dotan a sí mismas de la normativa aplicable, siendo las responsables últimas de todo condicionamiento de sus derechos que les afecte. Esto es especialmente relevante en materia tributaria, como se ocupa de señalar la STC 233/1999, de 16 de diciembre (RTC 1999/233), en su Fundamento Jurídico $10^{\circ}$. Vid. Galán Galán, Alfredo, La potestad normativa autónoma local, op. cit., pág. 202; LLiset Borrell, Francisco, Manual de Derecho local, op. cit., págs. 604 y 605.

${ }^{40}$ Esto es aún más evidente con la nueva redacción que ha dado a estos preceptos la Ley $57 / 2003$, de 16 de diciembre, de medidas para la modernización del gobierno local. Los artículos 127.1 y 129.1 LRJPAC cuando se trate de entes locales se limitan ahora a remitir a lo dispuesto por el nuevo Título XI de la LBRL, rubricado "Tipificación de las infracciones y sanciones por 


\section{CONCLUSIONES}

La STS de 29 de septiembre de 2003 (RJ 2003/6487) cambia, en el ámbito de su jurisprudencia, las coordenadas por las que se rigen las relaciones entre la ley y la norma local. El esquema de relaciones que se dan entre la ley y los reglamentos estatales o autonómicos no es aplicable cuando se trata de articular la interrelación entre la ley y la ordenanza local. Es necesario articular un sistema que permita cohonestar principio de legalidad y autonomía local, minimizando las tensiones existentes.

Lo que ya había dicho el Tribunal Constitucional, en sus sentencias de 16 de diciembre de 1999 (RTC 1999/233), para el ámbito tributario, y de 8 de junio de 2001 (RTC 2001/132), para el ámbito sancionador, lo confirma ahora el Tribunal Supremo, en el marco del Derecho administrativo sancionador.

Y es en este marco donde se declara por el Supremo la no aplicación, o aplicación flexible, de los artículos 127.1 y 129.1 LRJPAC cuando se trate de entes locales. La presencia del interés local, que se manifiesta en la norma local, requiere una reinterpretación de estos preceptos, que acepte las peculiaridades de la norma local.

las Entidades Locales en determinadas materias”, en el que se admite la modulación de la reserva de ley en este ámbito, conforme a la más reciente doctrina de la STC 132/2001, de 8 de junio (RTC 2001/132).

Respecto a esta imposibilidad de trasladar el modelo tradicional de relaciones ley-reglamento al campo local, vid. Blasco Díaz, José Luis, Ordenanza municipal y ley, op. cit., págs. 86-90; Galán Galán, Alfredo, La potestad normativa autónoma local, op. cit., págs. 227-230; Jerez Calderón, José Joaquín, "La potestad reglamentaria local", op. cit., pág. 60.

La doctrina española se ha referido a las peculiaridades de la norma local, como razón para aplicar un modelo distinto, vid. Galán Galán, Alfredo, La potestad normativa autónoma local, op. cit., págs. 87 y 88 , que afirma que estas peculiaridades significan que a la norma local le corresponde "una posición propia y diferenciada de aquella que corresponde al reglamento en sentido estricto"; Nieto García, Alejandro, Derecho Administrativo Sancionador, op. cit., págs. 123 y 124, donde NIETO afirma que "una Ordenanza no es parangonable con un Reglamento estatal", debido a la esfera dotada de autonomía en la que opera, así como a su no subordinación a otras normas procedentes del mismo ente; Parejo Alfonso, Luciano, La potestad normativa local, Marcial Pons, Madrid, 1998, págs. 37-41 y 43, que sostiene que la especificidad de la instancia territorial local excluye "la legitimidad de toda trasposición a la misma de la economía y la lógica de cualquiera de las instancias-ordenamientos superiores", lo que en el plano ordinamental se traduce, para PAREJo, en "la improcedencia de la equiparación entre las normas locales y las dictadas por los Gobiernos y las Administraciones de las instancias territoriales superiores", hasta el punto de que la LBRL denomina a las normas locales "ordenanzas", para así resaltar su peculiaridad dentro de la categoría de las normas reglamentarias. 
Esta reinterpretación supone no sólo la modulación del principio de reserva de ley sancionadora, aspecto éste en el que el Tribunal se limita a confirmar la doctrina del Constitucional, sino también la sustitución del principio de vinculación positiva de la ordenanza local a la ley por el principio de vinculación negativa. Es la recepción de esta doctrina de la vinculación negativa de la ordenanza local al principio de legalidad sancionadora la máxima aportación de la sentencia. Es en este punto donde el Tribunal Supremo pretende realizar una tarea integradora del ordenamiento jurídico, sentando jurisprudencia.

Este cambio de coordenadas resulta revalidado a nivel legislativo, en el marco del Derecho administrativo sancionador, por la nueva redacción que a los artículos 127.1 y 129.1 LRJPAC da la Ley 57/2003, de 16 de diciembre, de medidas para la modernización del gobierno local. Estos preceptos remiten ahora, cuando se trate de entes locales, a lo dispuesto por el nuevo Título XI de la LBRL, rubricado "Tipificación de las infracciones y sanciones por las Entidades Locales en determinadas materias", en cuyo articulado se refleja la modulación del principio de reserva de ley sancionadora, conforme a la jurisprudencia de ambos Tribunales, Constitucional y Supremo. Las coordenadas son ahora otras, no ya las establecidas por la LRJPAC, sino las definidas por la LBRL.

La otra gran aportación de la sentencia es la aplicación de la CEAL para la resolución del problema planteado. La CEAL es un Tratado internacional, pero no por ello carece de valor normativo, ni su valor es meramente programático. Se trata de una norma jurídica, integrada en el ordenamiento jurídico español desde su publicación en el $\mathrm{BOE}$, con valor y rango de ley, plenamente aplicable por nuestros Tribunales de Justicia. La sentencia del Tribunal Supremo silencia, de este modo, cualquier afirmación que pudiera hacerse en contra de su valor normativo.

\section{ANEXO JURISPRUDENCIAL}

Hacemos aquí, a mayor abundamiento, un breve repaso de la más reciente jurisprudencia del Tribunal Supremo sobre principio de legalidad sancionadora y ordenanza local, para así conocer los antecedentes jurisprudenciales más cercanos a la sentencia objeto de este trabajo, y que forman parte de su contexto. Nos detenemos, sin pretensión agotadora, en algunos de los pronunciamientos más importantes. 
Comenzamos por la STS de 29 de mayo de 1998 (RJ 1998/5457), que no aporta nada nuevo ni relevante, más allá de confirmar la doctrina restrictiva de las posibilidades de la ordenanza local en el ámbito sancionador ${ }^{41}$. En este caso, se discute si una ordenanza de policía urbana y gobierno del Ayuntamiento de Madrid, relativa al consumo de bebidas alcohólicas en la vía pública, está o no dotada de cobertura legal. En esta sentencia el Tribunal Supremo recuerda que el artículo $25.1 \mathrm{CE}$, además de una garantía de carácter material, que exige la predeterminación normativa de infracciones y sanciones, impone una garantía de carácter formal, referida al rango normativo necesario para la tipificación, rango que, conforme a la expresión "legislación vigente", ha de ser de ley. Todo ello implica la existencia de una reserva de ley en materia sancionadora.

Conforme a esta reserva de ley, una ordenanza municipal no puede ser fuente primaria de un ordenamiento sancionador, ni siquiera en el ámbito de las relaciones de sujeción especial, dependiendo la regulación por ordenanza en este campo de una previa regulación por ley, en lo que insisten los artículos 127 y 129 de la LRJPAC, aplicables a todas las Administraciones Públicas, también a la Administración local (F.J. $4^{\circ}$ ).

Esta exigencia de ley no puede suplirse por genéricas referencias a las competencias municipales sobre determinadas materias, al principio de autonomía local, a las competencias reglamentarias de los entes locales o a su facultad de dictar ordenanzas. Es necesaria una norma con rango de ley, que habilite al ente local para introducir el correspondiente régimen sancionador. Si no se da esta cobertura legal específica, la ordenanza no podrá entrar a tipificar infracciones y sanciones (F.J. $\left.5^{\mathrm{o}}\right)^{42}$.

\footnotetext{
${ }^{41}$ No obstante, a ARIAS MARTínez sí que le parece relevante esta sentencia, debido al momento en que se dicta, tras haber entrado en vigor el tan cuestionado Real Decreto 1398/1993, de 4 de agosto, por el que se aprueba el Reglamento del Procedimiento para el ejercicio de la Potestad Sancionadora. Ello supone un posicionamiento del Tribunal Supremo a favor de la tesis restrictiva, pese a que la existencia del RPS le podría haber llevado a lo contrario, lo que convierte su postura en especialmente relevante. Vid. Arias Martínez, María Antonia, "La potestad sancionadora de los entes locales y el principio de legalidad (a propósito de la STS de 29 de mayo de 1998)", op. cit..

${ }^{42}$ Los argumentos esgrimidos por el Ayuntamiento de Madrid son criticados por SánchEZ GoYANES, que comenta esta sentencia, y se ocupa de analizar detenidamente estos argumentos, en Sánchez Goyanes, Enrique, La potestad normativa del municipio español: ordenanzas, reglamentos, planes urbanísticos, normas, op. cit., págs. 290-295. También BALLESTEROS se hace cargo de esta sentencia, en Ballesteros Fernández, Ángel y Gieure Le Caressant, Javier, Los reglamentos y ordenanzas locales. Estudio especial del Reglamento orgánico, op. cit., pág. 24.
} 
Atendamos, a continuación, a la STS de 16 de julio de 1998 (RJ $1998 / 8381)^{43}$. En esta sentencia se cuestiona, entre otras cosas, la existencia de cobertura legal del régimen sancionador dispuesto en el articulado de una ordenanza del Ayuntamiento de Madrid reguladora del estacionamiento de vehículos en la vía pública. Como vamos a ver a lo largo de este epígrafe, este tipo de ordenanzas, más conocidas como ordenanzas de regulación del aparcamiento (ORA), son fuente frecuente de conflictividad. En este caso, la tipificación de infracciones viene determinada genéricamente por la transgresión de las disposiciones de la referida ordenanza. ¿Cuál es la ley que dota de cobertura legal a esta tipificación?.

El Supremo nos dice en esta sentencia que es "innecesario que la Ley de Régimen Local tenga que descender a la tipificación de todas y cada una de las posibles infracciones de todas las Ordenanzas Municipales". Los artículos 4.1.f) y 21.1.k $)^{44}$ de la LBRL y 59 del TRRL se consideran cobertura legal bastante (F.J. $\left.7^{\circ}\right)$.

Observamos en esta sentencia una postura más relajada con respecto a las exigencias del principio de legalidad sancionadora del artículo 25.1 CE, al menos en orden a la tipificación de infracciones y sanciones en el ámbito local, por medio de ordenanza local. Esta postura nos parece acertada, si bien creemos que debemos criticar que el Supremo no se esfuerce en buscar algún tipo de engarce legislativo sectorial, que refuerce aún más la habilitación legal de la ordenanza cuestionada. Lo que sí hará en su siguiente sentencia al respecto.

En la misma línea se sitúa la STS de 22 de septiembre de 1999 (RJ 1999/6728), en la que se cuestiona la existencia de habilitación legal de una ordenanza del Ayuntamiento de Santander, limitadora del estacionamiento en vía pública o reguladora del aparcamiento.

$\mathrm{Al}$ Tribunal Supremo le basta con la cobertura legal que suponen, por un lado, los artículos 4.1, 21.1.k), 25.2.b) y 84.1.a) LBRL, y 55 TRRL, y, por otro, los artículos 7.b), 38.4 y 39.1.c) del Real Decreto Legislativo 339/1990, de 2 de

${ }^{43}$ Esta sentencia es objeto de análisis en Ballesteros Fernández, Ángel y Gieure Le Caressant, Javier, Los reglamentos y ordenanzas locales. Estudio especial del Reglamento orgánico, op. cit., págs. 24-25.

${ }^{44}$ La Ley 11/1999, de 21 de abril, que reforma la LBRL en el marco del llamado Pacto Local modificó el contenido de este artículo, relativo a la competencia del Alcalde de establecer sanciones por infracción de las ordenanzas municipales. Ahora, esta competencia hay que venir a buscarla al artículo 21.1.n) LBRL, siendo otro el contenido del 21.1.k) LBRL. 
marzo, por el que se aprueba el texto articulado de la Ley sobre Tráfico, Circulación de Vehículos a Motor y Seguridad Vial (en adelante LSV) ${ }^{45}$.

No es necesaria una concreta tipificación legal de la conducta constitutiva de infracción. Basta con los citados preceptos de la LSV, y con las facultades normativas y competenciales atribuidas a los entes locales por la legislación de régimen local citada, para que por ordenanza puedan tipificarse infracciones y sanciones que regulen las condiciones del estacionamiento de vehículos en la vía pública.

El Tribunal Supremo nos recuerda en esta sentencia, que es doctrina legal sentada por este Tribunal, en su sentencia de 26 de diciembre de 1996 (RJ 1997/1233), al hilo precisamente de una ordenanza del Ayuntamiento de Santander limitadora del aparcamiento de vehículos, que las ordenanzas municipales reguladoras de las zonas de estacionamiento de vehículos no sólo pueden limitar el tiempo máximo de estacionamiento de éstos, sino que también cuentan con habilitación legal suficiente para tipificar como infracción administrativa el estacionamiento sin autorización, o con autorización pero excediendo del máximo de tiempo permitido. La mera contravención de la ordenanza puede considerarse infracción determinante de sanción.

A pesar del entendimiento flexible del principio de legalidad sancionadora que denota el Tribunal Supremo en esta sentencia, se sentía la necesidad de reformar la LSV, para así dar solución a los problemas que originaba la cuestión de la cobertura legal de las sanciones a imponer por los municipios en materia de ordenación de aparcamientos. Esta reforma se produjo por Ley 5/1997, de 24 de marzo, de Reforma del texto articulado de la Ley sobre Tráfico, Circulación de Vehículos a Motor y Seguridad Vial ${ }^{46}$ (F.J. $4^{\mathrm{o}}$ y $5^{\mathrm{o}}$ ).

\footnotetext{
${ }^{45}$ Hoy día estos preceptos obedecen a distinta redacción, dada la posterior reforma de este texto legal por Ley 5/1997, de 24 de marzo, de Reforma del texto articulado de la Ley sobre Tráfico, Circulación de Vehículos a Motor y Seguridad Vial. No es ésta la única reforma a la que se ha visto sometida la LSV con posterioridad, pero sí la que nos interesa a estos efectos.

Sobre la ordenación del tráfico por los Ayuntamientos, resulta de interés lo dispuesto en Sánchez Goyanes, Enrique, La potestad normativa del municipio español: ordenanzas, reglamentos, planes urbanisticos, normas, op. cit., págs. 181-192.

${ }^{46}$ Pasándose a prohibir expresamente la conducta objeto del recurso. Así, el nuevo artículo 7.b) de la LSV añade como competencia municipal "el establecimiento de medidas de estacionamiento limitado, con el fin de garantizar la rotación de los aparcamientos", y el nuevo artículo 39.2.b), de la misma Ley, prohíbe el estacionamiento "en los lugares habilitados por la autoridad municipal como de estacionamiento con limitación horaria, sin colocar el distintivo que lo autoriza o cuando colocado el dispositivo se mantenga estacionado el vehículo en exceso sobre el tiempo máximo permitido por la Ordenanza Municipal".
} 
La STS de 4 de febrero de 2002 (RJ 2002/2911) ${ }^{47}$ no encuentra cobertura legal suficiente para la tipificación de infracciones y sanciones realizada por ordenanza municipal de limpieza viaria del Ayuntamiento de Gijón. Esta ordenanza tiene su fundamento en la Ley 42/1975, de 19 de noviembre, sobre Residuos Sólidos Urbanos. Si bien, esta ley no habilita al Ayuntamiento para tipificar infracciones y sanciones por ordenanza. Tampoco los artículos 4.1.a), 25.2 y 26.1 LBRL, alegados por el Ayuntamiento de Gijón ${ }^{48}$, dan pie al Tribunal Supremo para dotar de cobertura legal a la ordenanza cuestionada.

Pese a ello, sólo se declara contraria a Derecho aquella parte del articulado de la ordenanza que tipifica infracciones y sanciones sin cobertura legal ${ }^{49}$. No es contraria al ordenamiento jurídico la parte de ésta que se limita a prohibir las conductas que han sido tipificadas como infracciones administrativas ${ }^{50}$. Puede resultar poco práctica la existencia de conductas cuyo cumplimiento no puede ser garantizado por la vía de la tipificación de la infracción, y su correspondiente sanción. Pero el Tribunal estima de interés para el Ayuntamiento mantener esta prohibición (F.J. $3^{\circ}$ y $\left.4^{\circ}\right)^{51}$.

No se produce, por tanto, ningún avance significativo en la jurisprudencia del Tribunal Supremo con esta sentencia. Más bien, se vuelve a la doctrina restrictiva de este Tribunal. Si bien, debemos destacar la observación hecha en el párrafo anterior respecto del fallo de la sentencia. Con esto, se pone de relieve la existencia de un problema importante, el de la existencia en el ámbito local de conductas cuyo cumplimiento carece de la garantía del Derecho sancionador.

En STS de 12 de junio de 2002 (RJ 2002/8201) ${ }^{52}$, en la que se cuestiona el régimen sancionador establecido en ordenanza municipal reguladora del

\footnotetext{
${ }^{47}$ De esta sentencia es Ponente MARIANO BAENA DEL ALCÁZAR. Queremos reseñarlo, porque también lo es de la sentencia objeto de este trabajo.

${ }^{48}$ Que sostiene, al respecto, la competencia de los municipios en materia de limpieza, además de su potestad reglamentaria.

${ }^{49}$ Concretamente, el párrafo segundo de su artículo 16.

${ }^{50}$ Nos estamos refiriendo al párrafo primero de su artículo 16.

${ }^{51}$ Sobre esta sentencia, vid. Menéndez Rexach, Ángel, "Crónicas de jurisprudencia”, Justicia Administrativa, núm. 18, 2003, págs. 110 y 111.

${ }^{52}$ De la que también es Ponente MARIANO BAENA DEL ALCÁZAR.
} 
servicio público de ordenación y regulación del aparcamiento de vehículos en la vía pública del Ayuntamiento de Segovia, el Tribunal viene a confirmar la jurisprudencia vertida en la citada STS de 22 de septiembre de 1999 (RJ 1999/6728). Los preceptos de la legislación de régimen local, y de la LSV, se consideran cobertura legal suficiente, para la tipificación de infracciones y sanciones realizada por la referida ordenanza (F.J. $2^{o}$ y $3^{\circ}$ ).

El Tribunal Supremo se remite expresamente a la forma en que se resolvió el problema que le afecta en sus STS de 17 de enero de 2002 (RJ 2002/894), 23 de enero de 2002 (RJ 2002/1846) y 29 de enero de 2002 (RJ 2002/902). Todas estas sentencias se referían expresamente a la doctrina de la STS de 26 de diciembre de 1996 (RJ 1997/1233), doctrina legal a la que ya nos hemos referido, dada la cita de la misma que hacía la STS de 22 de septiembre de 1999 (RJ 1999/6728), y que admitía la tipificación de infracciones y sanciones por ordenanza de regulación del aparcamiento. Vuelve aquí, el Tribunal, a trazar una línea favorable a las posibilidades de la ordenanza local en el ámbito sancionador.

Igual línea sigue la STS de 15 de julio de 2002 (RJ 2002/10136), relativa a ordenanza de regulación de aparcamientos de vehículos en las zonas de estacionamiento limitado de las vías urbanas del Ayuntamiento de Ávila. Esta sentencia confirma la corriente jurisprudencial trazada en las sentencias anteriores, al mostrarse también favorable a la tipificación de infracciones y sanciones por ordenanza local en esta materia ${ }^{53}$, entendiendo que existe habilitación legal bastante (F.J. $3^{\circ}$ ). De hecho, también cita expresamente las STS de 26 de diciembre de 1996 (RJ 1997/1233), 17 de enero de 2002 (RJ 2002/894), 23 de enero de 2002 (RJ 2002/1846) y 29 de enero de 2002 (RJ 2002/902), así como la STS de 16 de abril de 2002 (RJ 2002/6834), que resuelve en el mismo sentido.

La STS de 6 de junio de 2003 (RJ 2003/6857) recuerda la jurisprudencia del Tribunal Constitucional relativa al artículo 25.1 CE, que consagra el principio de reserva de ley en el ámbito sancionador administrativo, con una do-

${ }^{53}$ El Tribunal Supremo se ocupa, a su vez, de destacar la importancia que tiene el acertado ejercicio y la adecuada aplicación de las técnicas jurídicas empleadas en este tipo de ordenanzas. La utilización de estas técnicas viene justificada por la nueva y relevante dimensión pública que adquiere la ordenación del tráfico urbano en nuestros días. La libre circulación de vehículos y personas, el efectivo ejercicio de otros derechos tales como el acceso al puesto de trabajo, el disfrute de los servicios sanitarios, educativos y culturales, la protección del medioambiente y la defensa del Patrimonio Artístico, la calidad de vida en la ciudad, en definitiva. Todos ellos intereses colectivos que resultan salvaguardados por este tipo de ordenanzas (F.J. $3^{\circ}$ ). 
ble garantía. Por un lado, la necesaria predeterminación de la conducta constitutiva de infracción y de su correspondiente sanción. Por otro, la exigencia de que esta regulación se haga por norma con rango formal de ley ${ }^{54}$.

Esta doctrina lleva al Tribunal Supremo a concluir que la sanción dictada por el Ayuntamiento de Madrid ${ }^{55}$ no está dotada de cobertura legal suficiente. Esta sanción se impone en función de ordenanza municipal reguladora del servicio de autotaxi. El Ayuntamiento invoca el Real Decreto 763/1979, de 16 de marzo, por el que se aprobó el Reglamento nacional de los servicios urbanos e interurbanos de transportes en automóviles ligeros, como fundamento de esta ordenanza. Este Real Decreto no puede considerarse cobertura legal, ya que tiene rango reglamentario. Hubiera sido precisa una norma con rango de ley ${ }^{56}$.

La doctrina del Tribunal Supremo se ha mostrado vacilante sobre la necesidad o no de esta cobertura legal en el ámbito de las relaciones de sujeción especial. No obstante, en esta sentencia se inclina por exigir también habilitación legal cuando exista relación de sujeción especial. Que la relación de los titulares de licencias de autotaxi con el Ayuntamiento pueda considerarse una relación especial de sujeción no exime de la necesidad de habilitación legal previa.

El Tribunal Supremo hace todas estas consideraciones siguiendo la STC 132/2001, de 8 de junio (RTC 2001/132), que aborda una cuestión prácticamente idéntica. De este modo, entendemos que está también admitiendo la posibilidad de modular el principio de reserva de ley en el ámbito sancionador local, por cuanto ésta era la conclusión que se desprendía de esta importante sentencia del Tribunal Constitucional. Si bien, no reproduce textualmente el contenido de la misma en este extremo, y se limita a poner el acento en la necesidad de cobertura legal para la imposición de sanciones incluso en el ámbito de las relaciones de sujeción especial. En apoyo de su ar-

54 El Tribunal Supremo recuerda esta doctrina mediante la cita de la STC 42/1987, de 7 de abril (RTC 1987/42), en la que tiene su origen esta jurisprudencia, y de la STC 50/2003, de 17 de mayo (RTC 2003/50), exponente más reciente de la misma.

55 Consistente en suspensión temporal de la licencia de autotaxi.

56 Con posterioridad a la fecha de autos, por lo que no resulta aplicable, se dictó la Ley 20/1998, de 27 de noviembre, de Transportes Urbanos de la Comunidad Autónoma de Madrid, que remite a la regulación de las ordenanzas municipales en materia de infracciones, con referencia expresa a los autotaxis. 
gumentación cita también las STS de 10 de febrero de 1997 (RJ 1997/1407) y STS de 8 de octubre de 2001 (RJ 2002/5862), en las que se resuelve en el mismo sentido.

También reflexiona sobre las incógnitas que todavía persisten en relación con algunos supuestos de ejercicio de la potestad sancionadora local. Estas incógnitas se desprenden de la flexibilización que en ciertos supuestos viene haciendo el propio Tribunal Constitucional de la exigencia de reserva de ley en materia sancionadora, y de la colaboración de ley y reglamento con respecto a ella (F.J. $\left.2^{\circ}\right)^{57}$.

Y es a estas incógnitas a las que, en parte, va a responder el Tribunal Supremo en su Sentencia de 29 de septiembre de 2003 (RJ 2003/6487) ${ }^{58}$, que constituye el objeto de este trabajo.

En la STS de 10 de junio de 2003 (RJ 2003/5655), relativa a una sanción de suspensión de licencia de autotaxi, impuesta conforme a Ordenanza reguladora del servicio de vehículos de alquiler con aparato taxímetro del Ayuntamiento de Madrid, se nos vuelve a recordar la doctrina sobre el artículo 25.1 CE (F.J. $3^{\circ}$ ). Si bien, también se advierte del carácter abstracto y general de esta doctrina, que ha tenido que ser pormenorizada por el Tribunal Constitucional en diversos supuestos (F.J. $4^{\circ}$ ).

El Tribunal Supremo en esta sentencia vuelve sobre lo dispuesto por la STC 132/2001, de 8 de junio (RTC 2001/132), confirmando su doctrina, al reproducir literalmente el contenido de la misma (F.J. $6^{\circ}, 7^{\circ}$ y $8^{\circ}$ ). El Supremo entiende que la cuestión sometida a su enjuiciamiento ha sido ya decidida por el Tribunal Constitucional en la citada sentencia, en la que se abordó una cuestión prácticamente idéntica. Por ello, resuelve conforme a la doctrina sentada en la misma (F.J. $4^{\circ}$ y $\left.9^{\circ}\right)$.

\footnotetext{
${ }^{57}$ De estas incógnitas se hace eco el Voto Particular de la STC 132/2001, de 8 de junio (RTC 2001/132), formulado por FERNANDO GARRIDO FALLA, al que se adhiere MANUEL JIMÉNEZ DE PARGA.

${ }^{58}$ Lo cual es especialmente relevante si tenemos en cuenta que el Ponente de ambas sentencias es MARIANO BAENA DEL ALCÁZAR.
} 